"The impact of working capital management on cash holdings of large and small firms: evidence from Jordan"

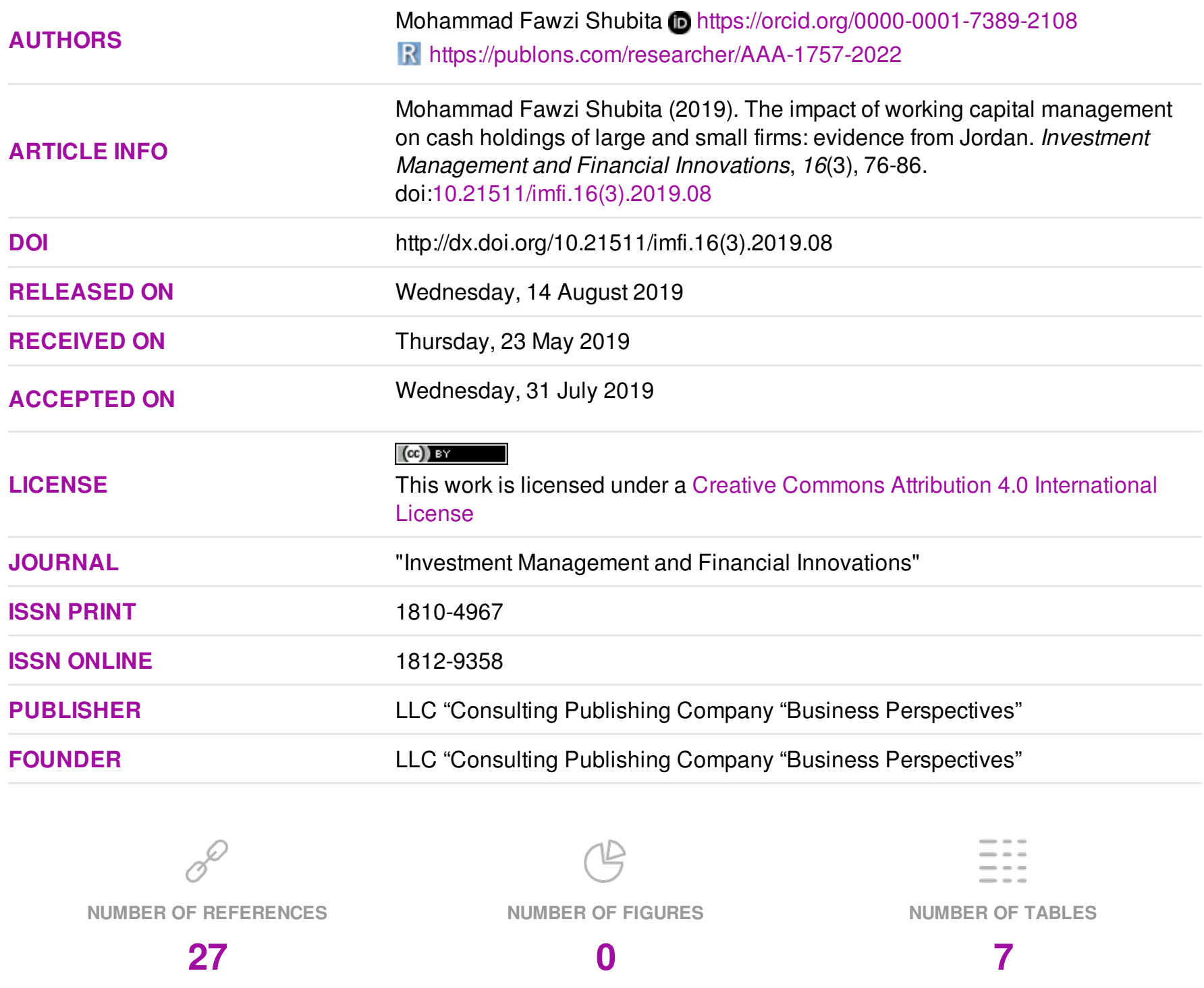

(C) The author(s) 2022. This publication is an open access article. 


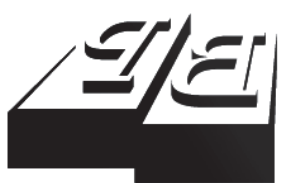

BUSINESS PERSPECTIVES

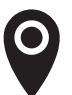

LLC "CPC "Business Perspectives" Hryhorii Skovoroda lane, 10, Sumy, 40022, Ukraine

www.businessperspectives.org

Received on: $23^{\text {rd }}$ of May, 2019 Accepted on: $31^{\text {st }}$ of July, 2019

(C) Mohammad Fawzi Shubita, 2019

Mohammad Fawzi Shubita, Ph.D. in Accounting, Associate Professor, Business Faculty, Department of Accounting, Amman Arab University, Jordan.

\section{THE IMPACT OF WORKING CAPITAL MANAGEMENT ON CASH HOLDINGS OF LARGE AND SMALL FIRMS: EVIDENCE FROM JORDAN}

\begin{abstract}
Liquidity is a firm's ability to pay its current obligations as they come due and thus remain in business in the short run, which reflects the ease with which assets can be converted to cash. The objective of working capital management (WCM) is to minimize the cost of maintaining liquidity while guarding against the risk of insolvency, working capital policy applies to short-term decisions, and capital structure finance applies to long-term decisions.

Several studies have been conducted on the impact of WCM on cash holding levels. The impact of WCM on liquidity and cash holding levels is analyzed in this study. The study also makes a comparison between large- and small-scale firms. Panel data for 62 Jordanian industrial firms covering an eleven-year period (2006-2016) have been analyzed. The descriptive analysis indicates that large firms hold more cash than small firms, as well as more debt, cash flow and growth.

The findings of the data set indicate that WCM, as a variable (working capital net of cash), is a strong predictor of firm cash holding levels. When a firm has several cash substitutes, it will maintain low cash levels. The separate analysis shows that there are significant differences between small- and large-scale firms for determinates related to cash holding levels. Firm size and cash flow ratios were strong predictors of cash holding levels for both samples.
\end{abstract}

Keywords

working capital management, cash holding, firm size, industrial companies, Jordan

JEL Classification M410

\section{INTRODUCTION}

Working capital is the difference between a current asset and a current liability of an organization. Thus, firms can enhance their liquidity position by virtue of increasing the amount of working capital.

Firms take into consideration the trade-off between risk and return, so WCM focuses on the quality of current asset items. The quality of current assets concerns the average time required for converting current assets into cash (Al-Debi'e, 2012). On the other hand, the quality of working capital takes into consideration whether a firm holds sufficient assets to cover its liabilities and to ensure that it has regular, sufficient, and consistent cash flow to fund its activities.

The way that working capital is managed has a significant impact on the cash holding levels of firms. Firms need to manage working capital as a substitute of cash holdings due to the following: if a firm's WCM is efficient, then the need to hold onto cash is reduced. 
The level of cash in a firm varies significantly according to the size of the firm. Large firms need to hold more cash due to large levels of activities, while small firms require less cash due to their low levels of activities. To be sure, small firms often keep high levels of cash, because they are more likely to suffer financial distress due to financial constraints, while large firms tend to keep low levels of cash in reserve due to the economies of scale (Gao et al., 2013).

Given the importance of the aforementioned concepts to an organization's success, this study will test the impact of WCM tools on cash holding levels. More specifically, this study will analyze the impact of WCM tools on the management structures of Jordanian industrial firms with respect to cash holding levels, with comparisons being made between small- and large-scale firms.

This study is organized as follows:

The research objectives and research problem are demonstrated, followed by a review of prior (related) literature and a demonstration of the theoretical framework of the impact of WCM on cash holdings and performance measures. Thereafter, the study methodology is introduced, which includes the study sample and period, the variables under examination, and the models of the study. Finally, the empirical results, conclusion and recommendations are reported.

\section{Research objectives}

The main objectives of this study are as follows:

1. Examine the relationship between WCM and cash holding levels of industrial firms.

2. Discover the differences between large- and small-scale firms regarding cash holdings and WCM.

3. Find the differences between working capital-related determinants of cash holding in large- and small-scale industrial Jordanian firms.

\section{Research problem}

This study has been conducted in order to identify determinants related to cash holding for large- and smallscale industrial firms. Moreover, the study was conducted in order to address the following questions - "Does WCM have an important influence on the level of cash holdings in Jordanian Firms? Do any differences exist between large- and small-scale Jordanian non-financial firms in term of cash holdings and WCM"? If so, what are the working capital-related determinants of Jordanian large- and small-scale industrial firms?

\section{LITERATURE REVIEW}

The study of Bates et al. (2009) discussed the reason why the average cash-to-asset ratio of industrial US firms increased by more than 50\% between 1980 and 2006. The study found that the average firm could pay off debt obligations with cash holdings. Furthermore, it was found that cash-to-asset ratio increase was due to the fact that, when a firm's cash flow becomes risky, said firm will hold fewer receivables and inventories.
Abu Zayed (2011) found a significant negative relationship between firm market value (as measured by Tobin's q) and the components of cash conversion cycles. Furthermore, he found a positive relationship between the profitability of non-financial Jordanian firms, which was measured by virtue of the gross operating profit, and the components of the cash conversion cycle.

Kaddumi and Ramadan (2012) examined the impact of WCM on firm performance for a sample of 49 Jordanian industrial listed corporations for 
the years 2005-2009. The study used the ordinary least squares model and the fixed effects model. The results suggested the following: performance and WCM are positively correlated; Jordanian industrial firms followed a conservative investment policy and a less aggressive financing policy with respect to working capital; efficient management of working capital can add value to shareholder wealth.

Yeboah and Agyei (2012) studied the impact of WCM on liquidity and profitability for banks in Ghana, using panel data for the years 1999-2008. The study found that both 'profitability' and 'creditor-payment periods' have a significant and positive relationship with cash position, while cash conversion cycles, debtor collection periods, bank size and capital structure have a significant and negative relationship with the cash position of banks.

Shubita (2013) examined the relationship between profitability and WCM for industrial listed Jordanian companies for the years 2004-2011. Using regression models, the study found a significant negative relationship between profitability and working capital variables (number of days-receivable, number of days-in-inventory, and number of accounts-payable days).

Anjum and Malik (2013) examined the determinants of cash holdings on non-financial companies of Pakistan listed on the Karachi Stock Exchange between the years 2005 and 2011. The study found a significant relationship between cash holdings and selected variables, such as net working capital, debt level size and cash conversion cycle. Furthermore, the study did not find the same relationship with sales growth.

Michalski (2014) reported on Polish firms a suggested approach to predict the most accurate from firm maximization point of view cash management and current assets management policy and discussed the results from operating risk that is related to current assets and cash management policy.

The study of Upadhyay et al. (2015) used data from hospitals in the state of Washington from 2002 to 2011 in order to study the relationship between profitability and cash conversion cycle. A fixed effects analysis was used, and the study found that, in general, managers increased hospital profitability by decreasing the duration of the cash conversion cycle.

Sharaf and Hadad (2015) analyzed the relationship between profitability and WCM components (using panel data analysis) for 43 industrial-listed Jordanian companies during the period 20002012. The results of regression analysis showed a significant negative relationship between profitability and cash conversion cycles. The results also showed that managers could create value for their shareholders by virtue of shortening both the inventory conversion period and the collection payment period, finding that profitability increases with size and sales growth and decreases with leverage.

Michalski (2016) discussed the risk sensitivity impact on enterprise decisions in area of net working capital investments and found on 4525 Romanian enterprises reported in Database Amadeus product of Bureau van Dijk that small net working capital leads some enterprises to negative changes in sales levels and to weaker profits.

Qurashi and Zahoor (2017) investigated working capital determinants for UK pharmaceutical industrial companies for the years 2009-2014, using the panel data method as an estimation tool. The multiple regression results showed a negative relationship between firm size and working capital and a positive relationship between growth and level of economic activity for UK pharmaceutical firms and working capital. Furthermore, insignificant results of working capital with profitability, operating cycle and leverage were observed.

The study of Jackpar et al. (2017) examined the impact of WCM on a firm's profitability, using a sample of 164 manufacturing companies listed in Malaysia over a period of five years from 2007 to 2011. Discriminatory panel regression and Pearson correlation were used to test the hypotheses. The study found that there is a significant positive relationship between firm's profitability and its average collection period, inventory conversion period and size. The findings showed a significant negative relationship between debt ratio and firm's 
profitability and that the cash conversion cycle had no impact on firm's profitability.

The study of Mahjabeen et al. (2018) aimed to analyze the WCM effect on corporate cash holdings, using a sample of 148 non-financial listed firms in Pakistan for the years 2004-2013. The study found that large and small companies need to remain high levels of cash substitutes.

Yunos et al. (2018) examined the effect of WCM on profitability among 803 companies listed in Malaysia for the period 2010-2014 using panel data analysis. The study found that the number of 'sales inventory days' and number of 'account receivable days' determined the profitability of industrial listed Malaysian firms and that the current ratio, the debt-to-equity ratio, and firm size had a significant impact on firm's profitability.

Al-Naif and Al Shra'ah (2019) studied the relationship between the working capital components of Jordanian industrial companies (inventory conversion period, payment period, receivables collection period and cash conversion cycle) and profitability. This study used company size and debt ratio as control variables. The study sample consisted of nine extraction industry companies listed between the years 2000 and 2016. The study employed correlation and panel data methodology, finding a negative relationship between the debt ratio and profitability of a firm, a strong negative relationship between the components of WCM and profitability, and a positive relationship between profitability and company size.

\section{LITERATURE REVIEW SUMMARY}

Prior studies have discussed several factors that affect WCM and cash holding and, from these studies, it is obvious that there is a negative relationship between profit and liquidity. Therefore, the financial decisions of a firm are often are concerned with (and therefore informed by) having high levels of liquid assets (such as cash and other current assets) and investments in more profitable assets and projects.
The impact of WCM on cash holding levels has also been discussed in previous studies, the findings of which suggest that a significant relationship exists between working capital variables and cash holdings, which means that companies have to remain high levels of cash substitutes to avoid liquidity risks.

In addition, firm size is also considered as an important factor in previous studies: large companies generate more profit and have more cash substitutes than small companies. Table 1 summarizes the main results of previous studies.

To contribute to the already existing body of literature, this study will attempt to establish a relationship between cash-holding levels and working capital determinates of large and small scale Jordanian industrial companies. In addition, this study examines whether WCM has an important effect on cash holdings level in Jordanian industrial companies.

Table 1. Main results of previous studies

\begin{tabular}{|c|c|}
\hline Study & Main results \\
\hline $\begin{array}{l}\text { Bates et al. } \\
\text { (2009) }\end{array}$ & $\begin{array}{l}\text { The average firm could pay off debt obligations } \\
\text { with cash holdings }\end{array}$ \\
\hline $\begin{array}{l}\text { Abu Zayed } \\
(2011)\end{array}$ & $\begin{array}{l}\text { Significant negative relationship between firm } \\
\text { market value (as measured by Tobin's q) and the } \\
\text { components of cash conversion cycles }\end{array}$ \\
\hline $\begin{array}{l}\text { Kaddumi and } \\
\text { Ramadan } \\
(2012)\end{array}$ & $\begin{array}{l}\text { Jordanian industrial firms followed a } \\
\text { conservative investment policy and a less } \\
\text { aggressive financing policy with respect to } \\
\text { working capital }\end{array}$ \\
\hline $\begin{array}{l}\text { Yeboah and } \\
\text { Agyei (2012) }\end{array}$ & $\begin{array}{l}\text { Profitability and creditor payment periods have } \\
\text { a significant and positive relationship with cash } \\
\text { holdings }\end{array}$ \\
\hline Shubita (2013) & $\begin{array}{l}\text { Significant negative relationship between } \\
\text { profitability and working capital variables }\end{array}$ \\
\hline $\begin{array}{l}\text { Anjum and } \\
\text { Malik (2013) }\end{array}$ & $\begin{array}{l}\text { Significant relationship between cash holdings } \\
\text { and net working capital }\end{array}$ \\
\hline $\begin{array}{l}\text { Upadhyay et } \\
\text { al. (2015) }\end{array}$ & $\begin{array}{l}\text { Managers increased hospital profitability by } \\
\text { decreasing the duration of the cash conversion } \\
\text { cycle }\end{array}$ \\
\hline $\begin{array}{l}\text { Sharaf and } \\
\text { Hadad (2015) }\end{array}$ & $\begin{array}{l}\text { Significant negative relationship between } \\
\text { profitability and cash conversion cycle }\end{array}$ \\
\hline $\begin{array}{l}\text { Qurashi and } \\
\text { Zahoor (2017) }\end{array}$ & $\begin{array}{l}\text { The negative relationship between firm size } \\
\text { and working capital and a positive relationship } \\
\text { between growth and level of economic activity }\end{array}$ \\
\hline $\begin{array}{l}\text { Jackpar et al. } \\
(2017)\end{array}$ & $\begin{array}{l}\text { There is a significant positive relationship } \\
\text { between a firm's profitability and its average } \\
\text { collection period, inventory conversion period } \\
\text { and size }\end{array}$ \\
\hline $\begin{array}{l}\text { Mahjabeen et } \\
\text { al. (2018) }\end{array}$ & $\begin{array}{l}\text { The study found that large and small companies } \\
\text { need to remain high levels of cash substitutes }\end{array}$ \\
\hline $\begin{array}{l}\text { Yunos et al. } \\
(2018)\end{array}$ & $\begin{array}{l}\text { The number of 'sales inventory days' and } \\
\text { number of 'account receivable days' determined } \\
\text { the profitability of industrial listed Malaysian } \\
\text { firms }\end{array}$ \\
\hline $\begin{array}{l}\text { Al-Naif and Al } \\
\text { Shra'ah (2019) }\end{array}$ & $\begin{array}{l}\text { Negative relationship between the debt ratio } \\
\text { and profitability of a firm }\end{array}$ \\
\hline
\end{tabular}




\section{THEORETICAL FRAMEWORK AND HYPOTHESES DEVELOPMENT}

The motives behind cash holding can be described in terms of three motives: the transaction motive, the precautionary motive and the speculative motive.

The transaction motive refers to the cash required by a firm to meet day-to-day operations, such as wages, interests, inventory and dividends. The precautionary motive refers to the need to hold onto money in order to meet contingency situations, such as a change in demand or an increase in the price of raw materials. The speculative motive refers to the need to hold onto money in order to benefit from future opportunities, such as falling prices of raw materials or high return investment opportunities (Kieso et al., 2018).

Thus, cash is the most liquid and significant asset that a firm holds. It is significant as it is used to help with the expansion of business operations and is used to pay off a firm's obligations.

WCM concerns the optimal level, mix, and use of current assets, as well as the means used to acquire them, notably current liabilities to minimize the cost of maintaining liquidity (quick convertibility to cash) while guarding against the risk of insolvency.

Two main working capital policies exist: conservative and aggressive. A conservative working capital policy seeks to minimize liquidity risk for a firm by increasing working capital. The firm seeks to ensure that adequate cash, supplies and inventory are available, and payables are minimized. The firm keeps that additional working capital available and forgoes the potentially higher returns from holding long-term assets. This policy is reflected in high current ratios (current assets current liabilities) and acid-test ratios (quick assets - current liabilities) (Gleim \& Flesher, 2018).

Aggressive working capital policies, on the other hand, consist of decreasing liquidity levels and increasing short-term cash flow problems in order to increase profitability. This policy is reflected in low current ratios and acid test ratios (Zutter, 2018).

The optimal level of current assets will vary depending on the industry in which a firm operates. For example, a grocery store has inventory and cannot carry more than a few days of sales. In contrast, a uranium mine must have a high level of cash to meet ongoing expenses, because its sales may be irregular (Gleim \& Flesher, 2018).

A firm's optimal level of cash should be determined by a cost benefit analysis. Indeed, cash itself does not earn returns. Accordingly, the amount of money held onto by a firm should correspond exactly to the amount needed to satisfy current obligations (Garrison et al., 2017). With this in mind, the following hypothesis can be developed:

\section{$H_{01}: \quad$ WCM does not have a significant impact on cash holdings.}

Firm size is a significant factor in determining WCM impact on cash holdings. Economic of scale associated with the cash levels needed to cover the normal transaction of the firm, so the larger firms can keep lower cash holdings. On the other hand, smaller firms suffer from financial constraints and financial distress (Yeboah \& Agyei, 2012).

Several factors can have an impact on a firm's cash holdings, all of which can be considered as control variables in study models. These factors include but are not limited to cash conversion cycle, leverage, firm size, sales growth, profitability, and cash flow.

The first determinant is the cash conversion cycle, which demonstrates how quickly a firm can transfer current assets into cash. In other words, short cash conversion cycle means that firms have efficient WCM systems and that they do not have to hold onto cash (Junli, 2011).

The leverage ratio measures a firm's level of debt. Firms that have large debt ratios (total debt/ total assets) tend to have smaller cash levels. Furthermore, firm size is considered as an important determinant due to the fact that large-scale firms hold onto more cash than small-scale firms in order to cover a wide range of activities and expenses (Bates et al., 2009). 
Growing firms need cash for investing. Sales growth includes economy of scale and needs a high level of inventory. Typically speaking, firms with large profits and high levels of cash flow exhibit greater cash holding levels than firms with high profitability and high cash flows (Yeboah \& Agyei, 2012).

The mechanisms of small firms are different than that of large firms due to the fact that they have to perform in different environments; thus, the factors that affect the WCM of small-scale firms are also different. Similarly, the working capital of small-scale firms might have a more obvious effect on cash holdings. In this manner, the factors that determine the cash holdings of small firms are different from that of large firms (Mahjabeen et al., 2018). In order to identify the possible differences in the determinants of small- and large-scale firms, the following can be hypothesized:

$H_{02}: \quad$ There are no significant differences between small- and large-scale firms with respect to the determinants of cash holding levels.

\section{RESEARCH METHODOLOGY}

Industrial shareholding companies listed in the Amman Stock Exchange that satisfy the following conditions will be included in the study sample:

1. Data required to calculate study variables should be between the years 2006 and 2016 .

2. Companies that entered a consolidation process will not be considered, as this will have an effect on company figures such as earnings.

After including these two conditions, 62 companies will represent the study sample.

Panel-data methodology is used for the analysis because this method has many advantages over conventional data sets such as cross-sections or time series; for instance, it increases the degree of freedom by reducing the multicollinearity among predictors (Raheman et al., 2010). In addition, the working capital-related determinants of firm cash-holding levels were analyzed separately for large- and small-scale firms, which is to say the sample set was divided into two categories: large-scale firms and small-scale firms. Firms were scaled based on their total assets (Pinkowitz et al., 2013), wherein a firm was considered to be large (and was set to "1") if its assets were above the median value, and a firm was considered to be small (and was set to "0") if its assess were below the median value. For the purpose of analysis, 'cash holding level' was considered as a dependent variable while 'working capital net of cash' was taken as the working capital-related determinant of cash holding. Furthermore, cash conversion cycle, cash flow ratio, financial leverage, firm size, and sales growth were taken as control variables. Table 2 illustrates variable type, denomination and computation.

Table 2. Variable type, denomination and computation

\begin{tabular}{|c|c|c|}
\hline $\begin{array}{l}\text { Type of } \\
\text { a variable }\end{array}$ & Variable & Computation \\
\hline $\begin{array}{l}\text { Dependent } \\
\text { variable }\end{array}$ & $\begin{array}{l}(\mathrm{CH}) \text { Cash } \\
\text { Holding }\end{array}$ & Cash/Total Assets \\
\hline $\begin{array}{l}\text { Independent } \\
\text { variable }\end{array}$ & $\begin{array}{l}\text { (WCNC) Working } \\
\text { Capital Net of } \\
\text { Cash }\end{array}$ & $\begin{array}{l}\text { (Current Assets-Current } \\
\text { Liabilities-Cash)/Total Assets) }\end{array}$ \\
\hline \multirow{5}{*}{$\begin{array}{l}\text { Control } \\
\text { variables }\end{array}$} & $\begin{array}{l}(C C C) \text { Cash } \\
\text { Conversion } \\
\text { Cycle }\end{array}$ & $\begin{array}{l}\text { Days Receivable + Days } \\
\text { Inventory - Days Payable }\end{array}$ \\
\hline & $\begin{array}{l}(F L) \text { Financial } \\
\text { Leverage }\end{array}$ & Total Liabilities/Total Assets \\
\hline & (SOF) Size & Log (Total Assets) \\
\hline & (GOF) Growth & $\left(\right.$ Sales $_{t}-$ Sales $\left._{t-1}\right) /$ Sales $_{t-1}$ \\
\hline & $\begin{array}{l}(\text { CFR) Cash Flow } \\
\text { Ratio }\end{array}$ & $\begin{array}{l}\text { (Net Income + Deprecation)/ } \\
\text { Total Assets }\end{array}$ \\
\hline
\end{tabular}

This methodology was originally developed by Yeboah and Agyei (2012) and was adapted by Mahjabeen et al. (2018). The regression equation used to test the whole sample is given in Model 1, while, in Model 2, the scale-dummy notion was excluded for the separate analysis of small- and large-scale firms.

Model 1:

$C H_{i t}=\alpha_{0}+\alpha_{1}\left(C C C_{i t}\right)+\alpha_{2}\left(W C N C_{i t}\right)+$

$+\alpha_{3}\left(F L_{i t}\right)+\alpha_{4}\left(S O F_{i t}\right)+\alpha_{5}\left(G O F_{i t}\right)+$

$+\alpha_{6}\left(C F R_{i t}\right)+\alpha_{7}\left(S D_{i t}\right)+e$. 
Model 2:

$$
\begin{aligned}
& C H_{i t}=\alpha_{0}+\alpha_{1}\left(C C C_{i t}\right)+\alpha_{2}\left(W C N C_{i t}\right)+ \\
& +\alpha_{3}\left(F L_{i t}\right)+\alpha_{4}\left(S O F_{i t}\right)+\alpha_{5}\left(G O F_{i t}\right)+ \\
& +\alpha_{6}\left(C F R_{i t}\right)+e .
\end{aligned}
$$

where $\mathrm{CH}$ - cash holding, $\mathrm{WCNC}$ - working capital net of cash, $C C C$ - cash conversion cycle, $F L$ - financial leverage, $S O F$ - size of firm, $G O F$ - growth of firm, $C F R$ - cash flow ratio, $S D$ - scale dummy (1 for large-scale firms and 0 for small-scale firms), it - term at $t$ time, $\alpha_{0}$ : the intercept of model. $\alpha_{i}$ : variables coefficients, $t$-time $-1,2 \ldots 11$ years, $e:$ the error term.

\section{DESCRIPTIVE ANALYSIS}

Table 3 shows the descriptive measures for the study variables after deleting outliers, which defined as the top and bottom $1 \%$ of the observations on each of the study variables. The mean value calculated for the cash ratio of Jordanian companies was $6 \%$. The average value of large firms was $6.3 \%$ and $5.6 \%$ for small firms, which indicates that small firms hold less cash than large firms. These results were similar to the results of Mahjabeen et al. (2018) with respect to industrial firms; however, they differed from the results of Yeboah and Agyei (2012) with respect to banks with respect to banks, which suggested that the cash ratio was $24.84 \%$. Indeed, Jordanian industrial firms require more than two years to convert cash. This long cash conversion cycle may lead to several liquidity problems.

The mean working capital value for the entire data set was $17.2 \%$. For large- and small-scale firms, it was $14.2 \%$ and $20.1 \%$, respectively, which suggests that small firms have more cash substitutes than large firms. Financial leverage percentage for the entire data set was $33.6 \%$, which means that industrial firms rely more on equity. Large firms have greater cash ratios, as well as immaterial growth rate percentages.

In summary, the descriptive analysis indicates that large firms hold more cash than small firms, as well as more debt, cash flow and growth.

\section{BIVARIATE CORRELATION}

Table 4 presents the correlation matrix for the study variables. The correlation between WCM and cash holding is negative but not statistically significant. The correlation between cash holding and cash conversion cycle is also negative, which is in line with expectations. Mahjabeen et al. (2018) had the same results.

As expected, financial leverage and cash holding are negatively and significantly related, which means that firms with a high level of debt don't need to hold cash. Firm size, firm growth and firm cash flow are positively related to cash holding levels, which is in line with expectations, while firm size correlation factor is insignificant. It is clear from this correlation matrix that the multicollinearity problem does not exist in the study variables. In addition, the variance inflation factor (VIF) was estimated for the two models, which is the ratio of actual disparity percentage and total disparity. The VIF for Model 1 is 1.8 and 1.6 for Model 2, both of which are smaller than that of Model 3. Accordingly, there is no multicollinearity problem in the regression mod-

\begin{tabular}{|c|c|c|c|c|c|c|}
\hline \multirow{2}{*}{ Variables } & \multicolumn{2}{|c|}{ Whole data set } & \multicolumn{2}{|c|}{ Large firms } & \multicolumn{2}{|c|}{ Small firms } \\
\hline & Mean & Std. dev. & Mean & Std. dev. & Mean & Std. dev. \\
\hline $\mathrm{CH}$ & 0.06 & 0.097 & 0.063 & 0.081 & 0.056 & 0.111 \\
\hline CCC & 777 & 741 & 720 & 666 & 835 & 808 \\
\hline WCNC & 0.172 & 0.201 & 0.142 & 0.165 & 0.201 & 0.228 \\
\hline SOF & 7.284 & 0.562 & 7.709 & 0.426 & 6.86 & 0.298 \\
\hline GOF & -0.012 & 0.306 & 0.020 & 0.285 & -0.046 & 0.324 \\
\hline$F L$ & 0.336 & 0.221 & 0.365 & 0.230 & 0.308 & 0.208 \\
\hline CFR & 0.035 & 0.099 & 0.057 & 0.087 & 0.014 & 0.105 \\
\hline
\end{tabular}
els (Gujarati \& Porter, 2009).

Table 3. Descriptive measures 
Table 4. Correlation matrix

\begin{tabular}{|c|c|c|c|c|c|c|}
\hline Variables & $\mathrm{CH}$ & CCC & WCNC & SOF & GOF & $F L$ \\
\hline$C C C$ & -0.089 & - & - & - & - & - \\
\hline WCNC & 0.020 & $(0.28)^{* * *}$ & - & - & - & - \\
\hline SOF & 0.043 & $(-0.19)^{* * *}$ & $(-0.14) * * *$ & - & - & - \\
\hline GOF & $(0.085)^{*}$ & $(-0.19)^{* * *}$ & 0.086 & $(0.14)^{* * *}$ & - & - \\
\hline$F L$ & $(-0.29)^{* * *}$ & $(-0.17)^{* * *}$ & $(-0.55)^{* * *}$ & $(0.11)^{* *}$ & $(-0.094)^{* *}$ & - \\
\hline CFR & $(0.28)^{* * *}$ & $(-0.12)^{* *}$ & $(0.18)^{* * *}$ & $(0.37)^{* * *}$ & $(0.30)^{* * *}$ & $(-0.36)^{* * *}$ \\
\hline
\end{tabular}

Notes: $* * *$ correlation is significant at the 0.01 level (2-tailed), ** correlation is significant at the 0.05 level (2-tailed), * correlation is significant at the 0.10 level (2-tailed).

\section{REGRESSION ANALYSIS}

Table 5 represents the first hypothesis coefficients; Model 1 is regressed first using the common effect analysis on the whole data set. The results demonstrate that working capital net of cash $(W C N C)$ is a significant predictor for firm's cash holding level. The negative coefficient predicts the relationship between WCNC and cash holding $(\mathrm{CH})$. This result is in line with Abel (2008) and Mahjabeen et al. (2018). So, $H_{01}$ can be rejected and we can say that WCM has a significant impact on cash holdings.

With respect to control variables, the firm leverage coefficient was significant with a negative relationship, which means that industrial firms use debt to reduce their cash position. This result is in agreement with the results of Yeboah and Agyei (2012) and Oppler et al. (1999). Furthermore, the results indicate that industrial firms with high growth rates tend to lower their cash levels. Therefore, industrial firms that have the greatest access to capital markets, such as firms with high growth percentages and high credit ratings, tend to hold lower cash-to-total-asset ratios.

The results confirm the fact that high-growth firms hold little cash because most of the available cash is invested in profitable long-term investments, instead of being stored in liquid or liquid equivalents.

The last control variable that has a significant relationship with cash level is the cash-flow ratio. Therefore, large cash-flow and high-profit firms have more cash holdings compared to firms with low profitability (Junli, 2011). Thus, profitable firms are likely to have more cash reserves than unprofitable firms.
Table 5. Determinants of cash holding $(\mathrm{CH})$

\begin{tabular}{l|c|c|c|c}
\hline Variable & Coefficient & $\begin{array}{c}\text { Std. } \\
\text { error }\end{array}$ & $\boldsymbol{t}$-statistic & Sig. \\
\hline Constant & 0.054 & 0.071 & 0.771 & 0.441 \\
CCC & -0.0004 & 0.000 & -0.831 & 0.407 \\
WCNC & -0.049 & 0.022 & -2.194 & 0.029 \\
SOF & 0.003 & 0.010 & 0.294 & 0.769 \\
GOF & -0.030 & 0.012 & -2.339 & 0.017 \\
\hline$F L$ & -0.071 & 0.021 & -3.459 & 0.001 \\
\hline$C F R$ & 0.342 & 0.046 & 7.488 & 0.000 \\
SD & 0.003 & 0.010 & 0.337 & 0.736 \\
R-squared & 0.241 & Adj. $R$-squared & 0.229 \\
\hline S.E. of & 0.0679 & Sum of squares residual & 1.999 \\
regression & 0.0679 & & 0.000 \\
\hline$F$-statistics & 19.708 & \multicolumn{2}{|c}{ Sig. } & \\
\hline
\end{tabular}

Model 2 was used to separately analyze the largeand small-scale samples. This was done in order to choose the appropriate measures from both fixed effect and random effect approaches. The Hausman (1978) test was used to demonstrate a significant $p$-value (0.000), so a fixed effect model was an appropriate model for this data set. The comparison of cash-holding determinants between large- and small-scale firms is presented in Table 6 and Table 7.

Table 6. Determinants of cash holding (CH) (large firms)

\begin{tabular}{|c|c|c|c|c|}
\hline Variable & Coefficient & Std. error & $t$-statistic & Sig. \\
\hline Constant & -0.168 & 0.085 & -1.973 & 0.050 \\
\hline$C C C$ & -0.0002 & 0.000 & -0.436 & 0.663 \\
\hline WCNC & -0.038 & 0.031 & -1.250 & 0.212 \\
\hline SOF & 0.028 & 0.011 & 2.592 & 0.010 \\
\hline GOF & -0.049 & 0.018 & -2.678 & 0.008 \\
\hline$F L$ & -0.024 & 0.026 & -0.950 & 0.343 \\
\hline CFR & 0.528 & 0.066 & 7.949 & 0.000 \\
\hline$R$-squared & 0.406 & \multicolumn{2}{|c|}{ Adj. $R$-squared } & 0.390 \\
\hline $\begin{array}{l}\text { S.E. of } \\
\text { regression }\end{array}$ & 0.063 & \multicolumn{2}{|c|}{ Sum of squares residual } & 0.902 \\
\hline F-statistics & 25.861 & \multicolumn{2}{|c|}{ Sig. } & 0.000 \\
\hline
\end{tabular}


Table 7. Determinants of cash holding (CH) (small firms)

\begin{tabular}{|c|c|c|c|c|}
\hline Variable & Coefficient & $\begin{array}{l}\text { Std. } \\
\text { error }\end{array}$ & $t$-statistic & Sig. \\
\hline Constant & 0.818 & 0.133 & 6.154 & 0.000 \\
\hline $\mathrm{CCC}$ & -0.001 & 0.000 & -1.651 & 0.100 \\
\hline WCNC & -0.050 & 0.030 & -1.688 & 0.093 \\
\hline SOF & -0.016 & 0.019 & -5.548 & 0.000 \\
\hline GOF & -0.025 & 0.016 & -1.585 & 0.115 \\
\hline$F L$ & -0.075 & 0.031 & 2.384 & 0.018 \\
\hline CFR & 0.239 & 0.057 & 4.212 & 0.000 \\
\hline$R$-squared & 0.239 & \multicolumn{2}{|c|}{ Adj. $R$-squared } & 0.216 \\
\hline $\begin{array}{l}\text { S.E. of } \\
\text { regression }\end{array}$ & 0.0641 & \multicolumn{2}{|c|}{ Sum of squares residual } & 0.826 \\
\hline$F$-statistics & 10.513 & \multicolumn{2}{|c|}{ Sig. } & 0.000 \\
\hline
\end{tabular}

Cash conversion cycle (CCC) is insignificant for the large- and small-scale firms, which means that CCC does not have any relation to cash levels, which itself is against the general rationale supported by the results of Mahjabeen et al. (2018) and Junli (2011). WCNC is significant for small firms only, with negative coefficients for both of the subsamples. Therefore, the higher the cash substitute, the lower the need to hold cash. This is because cash substitutes can be converted quickly into cash.

Financial leverage is insignificant for large companies and significant for small companies. Furthermore, firm size is significant in the smallscale firm subsample. This is because the cash-flow ratio has a positive relationship with cash holding level. Lastly, growth-of-sales results were different for subsamples: significant for large-scale firm and insignificant for small-scale firms.

The differences in the coefficients of the determinates of cash-holding levels between largeand small-scale firms - with the adj. $R$-squared between the two subsamples being $21.6 \%$ for small firms and $39 \%$ for large firms - lead us to reject the second null hypothesis. Accordingly, we can say that there are significant differences between small-and large-scale firms with respect to the determinants related to cash holding levels.

\section{CONCLUSION}

Several studies have been conducted on the impact of WCM on cash holding levels. This study contributes to existing literature by extending the area of inquiry to industrial firms in Jordan. The results of the study strongly demonstrate that WCM, financial leverage, firm growth, and profitability are key factors in explaining the level of cash held by industrial firms in Jordan. In addition, there are significant differences in the impact of these factors on small- and large-scale firms.

The descriptive analysis indicates different attributes of large- and small-scale firms. The following are found in small-scale firms: low cash holding levels, long cash conversion cycles, small financial leverage, and small growth and profitability. On the other hand, the following are found in large-scale firms: large financial leverage, large growth rates and profitability, lesser cash days of cash conversion cycle and low cash holding levels.

Regression was estimated using panel data, finding that WCM is a strong predictor of a firm's cash levels. A negative coefficient means that, when a firm has several cash substitutes, it will maintain low cash levels. Thereafter, the subsamples were separately analyzed. Firm size and cash-flow ratios were strong predictors of cash holding levels for both samples.

Overall, we can assert that large- and small-scale industrial Jordanian firms are different in terms of cash holding levels and WCM. Small-scale firms need to concentrate on financial leverage and cash flow. Large-scale firms need to increase sales growth rates and, in order to maintain a suitable cash position, they need to gain profitable investment opportunities. 


\section{REFERENCES}

1. Abel, M. (2008). The Impact of Working Capital Management on Cash Holdings - A Quantitative Study of Swedish Manufacturing SMEs. Department of Social Sciences. Aachen: Mid Sweden University. Retrieved from https://www.researchgate.net/ publication/277872854_The_Impact_of_Working_Capital_Management_on_Cash_Holdings_A_ Quantitative_Study_of_Swedish_Manufacturing_SMEs

2. Abuzayed, B. (2012). Working capital management and firms' performance in emerging markets: the case of Jordan. International Journal of Managerial Finance, 8(2), 155-179. https://doi. org/10.1108/17439131211216620

3. Al-Debie, M. (2012). Working Capital Management and Profitability: The Case of Industrial Firms in Jordan. European Journal of Economics, Finance and Administrative Sciences, 36, 75-86. Retrieved from https://www.researchgate.net/ publication/284029352_Working_Capital_Management_and_ Profitability_The_Case_of_Industrial_Firms_in_Jordan

4. Al-Naif, K., \& Al Shra’ah, A. (2019). Working capital management and profitability: Evidence from Jordanian mining and extraction industry sector. IUG Journal of Economics and Business, 27(1), 42-60. Retrieved from http://journals.iugaza.edu. ps/index.php/IUGJEB/article/ view/4938

5. Anjum, S., \& Malik, Q. A. (2013). Determinants of Corporate Liquidity - An Analysis of Cash Holdings. Journal of Business and Management, 7(2), 94-100. http://dx.doi. org/10.9790/487X-07294100

6. Bates, T. W., Kahle, K. M., \& Stulz, R. M. (2009). Why Do U.S. Firms Hold So Much More Cash than They Used To? The Journal of Finance, 64(5), 1985-2021. Retrieved from https://onlinelibrary.wiley.com/doi/pdf/10.1111/ j.1540-6261.2009.01492.x
7. Gao, H., Harford, J., \& Li, K. (2013). Determinants of corporate cash policy: Insights from private firms. Journal of Financial Economics, 109, 623-639. Retrieved from https://papers.ssrn. com/sol3/papers.cfm?abstract_ id $=2023999$

8. Garrison, R., Noreen, E., \& Brewer, P. (2017). Managerial Accounting (16th ed.). McGrawHill Education. Retrieved from https://www.mheducation.com/ highered/product/managerialaccounting-garrison-noreen/ M9781260153132.html

9. Gleim, I., \& Flesher, D. (2018). CMA Review, Part 2: Financial Decision Making (16th ed.). Gleim Publications. Retrieved from https://www.amazon.com/CMAReview-Part-Financial-Decision/ $\mathrm{dp} / 158194201 \mathrm{X}$

10. Gujarati, D. N., \& Porter, D. C. (2009). Basic Econometrics (5th ed.). McGraw-Hill. Retrieved from https://www. academia.edu/15273562/ Basic_Econometrics_5th_Edition_by_Damodar_N._Gujarati_ and_Dawn_C._Porter_

11. Jakpar, S., Tinggi, M., Siang, T. K., Johari, A., \& Myint, K. T. (2017). Working Capital Management and Profitability: Evidence from Manufacturing Sector in Malaysia Journal of Business and Financial Affairs, 6(2), 1-9. Retrieved from https://www.researchgate.net/ profile/Shaharudin_Jakpar/ publication/318424558_Working Capital_Management_and_Profitability_Evidence_from_Manufacturing_Sector_in_Malaysia/ links/596d7c0aa6fdcc03edb6ceee/ Working-Capital-Managementand-Profitability-Evidence-fromManufacturing-Sector-in-Malaysia.pdf

12. Junli, Z. (2011). Relationship between Working Capital Management and Corporate Cash Holdings. University of Eastern Finland, Department of Business. Retrieved from http:// epublications.uef.fi/pub/urn_nbn_ fi_uef-20110143/urn_nbn_fi_uef20110143.pdf
13. Kaddumi, T. A., \& Ramadan, I. Z. (2012). Profitability and Working Capital Management The Jordanian Case. International Journal of Economics and Finance, 4(4), 217-226. https://doi. org/10.5539/ijef.v4n4p217

14. Kieso, D., Weygandt, J., \& Warfield, T. (2018). Intermediate Accounting IFRS (3rd ed.). Wiley. Retrieved from https://www.wiley. com/en-us/Intermediate+Account ing\%3A+IFRS+Edition $\% 2 \mathrm{C}+3 \mathrm{rd}+$ Edition-p-9781119372936

15. Mahjabeen, Raheman, A., \& Rizwan, F. (2018). Working Capital Management and Corporate Cash Holdings: A Comparative Analysis of Large and Small Scale Non-Financial Pakistani Firms. Journal of Social Sciences, 18, 1-12. Retrieved from http://ajss.abasyn.edu.pk/ admineditor/specialissue/papers/ AICTBM-2018-5.pdf

16. Michalski, G. (2014). Value Maximizing Corporate Current Assets and Cash Management in Relation to Risk Sensitivity: Polish Firms Case. Economic Computation and Economic Cybernetics Studies and Research, 48(1), 259-276. Retrieved from https://papers.ssrn.com/sol3/papers.cfm?abstract_id $=2442862$

17. Michalski, G. (2016). Risk pressure and inventories levels. Influence of risk sensitivity on working capital levels. Economic Computation and Economic Cybernetics Studies and Research, 50(1), 189-196. Retrieved from https://ideas.repec.org/a/cys/ecocyb/v50y2016ilp189-196.html

18. Oppler, T., Pinkowitz, L., Stulz, R., \& Williamson, R. (1999). The Determinants and Implications of Corporate Cash Holdings. Journal of Financial Economics, 52(1), 3-46. https://doi.org/10.1016/ S0304-405X(99)00003-3

19. Pinkowitz, L., Stulz, R. M., \& Williamson, R. (2013). Is there a U.S high cash holdings puzzle after the financial crisis? (Working paper). Georgetown, Ohio State, United Kingdom. Retrieved from 
https://papers.ssrn.com/sol3/papers.cfm?abstract_id $=2253943$

20. Qurashi, M., \& Zahoor, M. (2017). Working Capital Determinants for the UK Pharmaceutical Companies Listed on FTSE 350 Index. International Journal of Academic Research in Accounting, Finance and Management Sciences, 7(1), 11-17. Retrieved from https://ideas.repec.org/a/hur/ijaraf/v7y2017i1p11-17.html

21. Raheman, A., Afza, T., Qayyum, A., \& Bodla, M. A. (2010). Working Capital Management and Corporate. International Research Journal of Finance and Economics, 47, 151-163. Retrieved from https://www.researchgate.net/ publication/50341524_Working_ Capital_Management_and_Corporate_Performance_of_Manufacturing_Sector_in_Pakistan

22. Sharaf, R., \& Haddad, F. (2015). The Relationship between
Working Capital Management and Profitability for Industrial Companies Listed in Amman Stock Exchange. Jordan Journal of Business Administration, 11(2), 509-523. Retrieved from https:// journals.ju.edu.jo/JJBA/article/ view/9466

23. Shubita, M. (2013). Working Capital Management and Profitability: A Case of Industrial Jordanian Companies. Contemporary Research in Business and Social Science, 4(8), 108115. http://www.ijbssnet.com/ journals/Vol_4_No_8_Special_Issue_July_2013/10.pdf

24. Upadhyay, S., Sen, B., \& Smith, D. (2015). The cash conversion cycle and profitability. A study of hospitals in the state of Washington. The Journal of Health Care Finance, 41(4). Retrieved from http://healthfinancejournal. com/index.php/johcf/article/ view/29
25. Yeboah, B., \& Agyei, K. (2012) Working Capital Management and Cash Holdings of Banks in Ghana. European Journal of Business and Management, 4(13), 2222-2839. Retrieved from http://citeseerx.ist. psu.edu/viewdoc/download?doi=10 1.1.734.9710\&rep $=$ rep $1 \&$ type $=$ pdf

26. Yunos, R. M., Ghapar, F. A., Ahmad, S. A., \& Sungip, N. (2018). Working capital management and its effect on profitability: Empirical evidence from Malaysian capital market. Insight Journal, 1(1), 71-87. Retrieved from https://www.researchgate. net/publication/322785834_Working_Capital_Management_and_ Its_Effect_on_Profitability_Empirical_Evidence_from_Malaysian_Capital_Market

27. Zutter, C. (2018). Principles of Managerial Finance (15th ed.). Retrieved from https://www.pearson.com/uk/educators/highereducation-educators.html 